\title{
A study on the ecology and economic impact of major invasive weed species of coconut homesteads of Nattika, India.
}

\author{
Abhilash ES ${ }^{1}$, Sheeja P Parayil' ${ }^{1}$ Brijesh Sathian², AR Raju ${ }^{3}$, Bilal NA ${ }^{4}$ and Kafsa Bind Salih ${ }^{4}$
}

${ }^{1}$ Assistant Professor, P.G. Department of Botany, Sree Narayana College, Nattika, Thrissur, Kerala, India.

${ }^{2}$ Assistant Professor, MCOMS, Pokhara, Nepal.

${ }^{3}$ Associate Professor, P.G. Department of Botany, Sree Narayana College, Nattika, Thrissur, Kerala, India.

${ }^{4}$ U.G. Student, P.G. Department of Botany, Sree Narayana College, Nattika, Thrissur, Kerala, India.

\begin{tabular}{l}
\hline Original Article \\
\hline Corresponding Author \\
Dr. Abhilash ES \\
Assistant Professor, P.G. Department of Botany \\
Sree Narayana College \\
Nattika, Thrissur, India \\
Email: abhies@gmail.com \\
Abstract
\end{tabular}

Out of the 4 alien invasive species three are of high risk namely Mikania micrantha, Chromolaena odorata and Mimosa diplotricha. Lantana camara is found to be medium risk. The farmers spent a considerable amount of money nearly Rs 4800 per year for one acre land pertaining to mechanical weeding of invasive species. The herbicide is widely used by farmers to control the weeds are capable to cause various health problems including genetic aberration. So an effective and comprehensive weed management strategy have to be developed in the country to combat the threats of IAS in agriculture fields.

Key Words: Invasive Alein Weeds, Mikania micrantha, Chromolaena odorata and Mimosa diplotricha. Lantana camara.

\section{Introduction}

Invasive weeds are herbaceous plants which are not considered for use or beauty, growing and regarded as cumbering the ground or hindering the growth of superior vegetation. Species which cross over their of natural distribution and get introduced to new habitats are known as alien species (Saxena, 1991). Invasive alien weeds have been creating a major problem in India by means of ecological, economical and biodiversity depletion. Some of them were introduced for ornamental aspects, as cover crops, for soil stabilization without knowing their ability of hazardous nature but many others were accidentally introduced while propagules of such weeds also transported along with food grains.
It is estimated that out of about 45,000 species of plants recorded from India, nearly 1,800 are alien and out of the known 54, 430 arthropods (including insects), nearly 1, 100 are alien. Thus IAS have become an environmental issue of concern (Sankaran, 2002).

In the agricultural sector more attention to the management of alien invasive weeds is given because of the social needs attached to the farming community. No serious attempt has been made in the past to look at the intersectoral problems related to alien invasive species.

Since the coconut cultivation is one of the major agriculture livelihood for central Kerala, this study attempts to review the threat by major alien invasive plants to the Coconut orchards of Nattika, a coastal region located in India, in the light of its invasion ecology and economic impact etc.

\section{Material and Methods}

Agriculture homesteads in Nattika were taken randomly selected for the study. One acre land area was demarcated for studying the weed density in each homestead. Altogether 5 acres of land were explored at 05 sites in various coconut homestead gardens. Indigenous methods of eradication of these invasive weeds cost of mechanical weeding and chemical control by farmers were also recorded.

\section{Results:}

Four major weeds have been identified from the selected homested gardens of Nattika which causes severe threat to coconut growers by decrease in yield and there by economic loss. They are

\section{1) Chromolaena odorata (L)R.M. King\& Robinson .}

\section{Family: Asteraceace}

Synonyms: Eupatorium odoratum

Common names: Siam weed, bitter bush.

Local name: Communist pacha, Katt Appa, Muri pacha.

Nativity: Native of tropical America.

Taxonomy:

Asia Pacific Journal of Environment Ecology and Sustainable Development 2013; 1:32-35

(An International Peer Reviewed Journal)Copyright (C) 2013 ATRFCE

Published online by NepJOL-INASP

www.nepjolinfo/index.php/APJEESD 
Habit: A herb 12 inches height with thin stem and widely diverging branches.

Leaves: Triangular- ovate, entire at the apex, coarsely toothed at the base, three nerved.

Flowers: Heads in corymbs terminating the braches, cylindrical, florets about 20.Involucral bracts, imbricate, obtuse, strongly three nerved.

\section{2) Lantana camara $L$.}

Family: Verbenaceace

Synonyms: Camara vulgaris, Lantana scabrida

Common names: Sleeper weed, lantana, wild sage

Local name: Aripoo,Kongini, Unnipoo etc.

Nativity: Tropical and subtropical regions of central and south America, the Caribbean and West Indies.

Taxonomy: Habit: Erect or subsandent, often strong smelling, pubescent or scabrous shrubs; branches 4- angled, sometimes prickly.

Leaves: Simple, opposite or ternate, crenate, often rugose.

Flowers: Pedunculate, capitates, ovoid or cylindrical spikes, bracts conspicuous, persistent bracteoles; Calyx small, membraneous, truncate or toothed; Corolla tube cylindric, slender; limb salver shaped; lobes 4 or 5, spreading; Stamens 4 , didynamous, included in the corolla-tube and inserted at its middle; anthers oblong, the cells parallel. Ovary 2 celled; ovules 1 in each cell; style short; stigma oblique, sub capitates.

\section{3) Mikania micrantha H.B.K.}

\section{Family: Asteraceace}

Common names: American rope, Chineese creeper, mile-aminute weed, mikania Local name: Silk vally, Kaipu vally, Dhritarashtra Pacha etc.

Nativity: Tropical and subtropical zones of northern, central and south America. It was introduced in northeast India sometime in the early 1900's as a cover crop in tea plantations.

Taxonomy: Habit: Perennial twining herb, branches 5 ribbed, pubescent or glabrous..

Leaves: Opposite, ovate-deltoid, 6-15 X 3-9 cm, base cordate, apex acuminate, margin coarsely dentate, petiole $3-7 \mathrm{~cm}$ long

Flowers: 4 per capitula, involucral bracts 4 , oblong to obovate, acute, green, 1-3mm long, corolla 5 lobed, white often with a purple tinge, 4-5 $\mathrm{mm}$ long

\section{4) Mimosa diplotricha C.Wright. Family: Mimosaceae}

Common names: Giant sensitive plant, creeping sensitive plant

Local name: Anatottavadi, Padaincha etc.
Nativity: Native of Tropical America. It was introduced in east asia in the 1960 as a nitrogen fixing plant in tea gardens.

\section{Taxonomy:}

Habit: Fast growing erect shrub and a scrambling climber which can form dense thickets in short span of time.

Leaves: Leaves are bright green, feathery, alternate, each leaf with about 20 pairs of small leaflets, bipinnate, sessile, opposite, lanceolate, acute, 6-12 mm long and $1.5 \mathrm{~mm}$ wide

Flowers: The inflorescence is a clustered fluffy ball, about 12 $\mathrm{mm}$ across, pale pink, occurs on short stalks in leaf joints. Corolla gamopetalous, stamen twice as many as petals.

The table. 1 shows infestation density of AIS where Mikania micrantha showed high density 1152 , followed by Chromolaena odorata (704), Mimosa diplotricha (256) and Lantana camara (34) respectively.

\section{Table- 1.Mean density of the Invasive species}

\begin{tabular}{|l|l|c|c|}
\hline SI No. & Name of the Invasive species & Mean density & Area \\
\hline 1 & Chromolaena odorata & 704 & One Acre \\
\hline 2 & Lantana camara & 34 & One Acre \\
\hline 3 & Mikania micrantha & 1152 & One Acre \\
\hline 4 & Mimosa diplotricha & 256 & One Acre \\
\hline
\end{tabular}

The table. 2 shows the cost of weeding which clearly indicates that mechanical weeding by labours entail a marginally high economic burden to the coconut farmers compared to other methods.

Table-2. The cost of different different weeding types.

\begin{tabular}{|l|l|l|l|l|}
\hline SI.NO & Type of weeding & Cost of Weeding & Area & \multicolumn{1}{|c|}{ Remarks } \\
\hline 1 & $\begin{array}{l}\text { Mechanical } \\
\text { labour weeding }\end{array}$ & Rs.4800/Year & One Acre & $\begin{array}{l}\text { Cost for } \\
\text { two times/Year }\end{array}$ \\
\hline 2. & $\begin{array}{l}\text { Bush cutter } \\
\text { Machine }\end{array}$ & Rs. $1600 /$ Year & One Acre & $\begin{array}{l}\text { Cost for two } \\
\text { times/Year }\end{array}$ \\
\hline 3. & Chemical control & Rs. $3018 /$ Year & One Acre & $\begin{array}{l}\text { Cost for two } \\
\text { times/Year }\end{array}$ \\
\hline
\end{tabular}

\section{Discussion:}

Chromolaena odorata is a perennial shrub, native to South and Central America, and capable of establishing in a wide variety of agro-ecological conditions. Chromolaena odorata is a serious problem in pastures, forests, orchards and commercial plantations in South and Northeast India (Singh 1998). It is widespread in coconut, cashew, tapioca cultivated lands and also in natural areas like saced groves. Cutting close to the ground, uprooting, controlled burning and digging out the root system are commonly used as Mechanical and Physical Control. The chemical control include the use of 
herbicides like Glyphosphate, Paraquat, triclopyr ester etc. Biological control have shown some success in controlling particularly in Indonesia (Sankaran et.al,2009).

Lantana camara is a terrestrial weed of South and Central American origin introduced as an ornamental plant in 1809 to India. This weed spreads in agro-ecosystems and adversely affects the crop yield.

In forests, Lantana is considered as a potential fire prone element in deciduous forests and it is combustible even when green. Lantana also has an inter-competence with agricultural crops with an allelopathic effect - inhibiting the growth of other plants. This weed is reported to be of concern in teak, eucalypt and coffee plantations in India (Sankaran et.al,2009).

Various attempts were made by the Forest Research Institute, Dehra Dun to identify insects that feed on Lantana. In 1941, a tingid bug, Teleonema scrupulosa, was imported from Australia as a biocontrol agent (Sankaran, 2002).

Mikania micrantha has been a serious problem for the coconut growers because of its fast growth and if not properly removed it will entirely cover the coconut seedlings as well as intercrops associated with coconut orchards within a short span of time.

Many insects have been investigated to feed on Mikania. In India, several studies are being made to assess the potential of an exotic rust fungus, Puccinia spegazzinii against Mikania (Sankaran, 2002). Successful elimination with 2,4-D compounds against Mikania has been reported but its toxic action on biota and long persistence (Williamson, 1996), make it unsuitable.

Mimosa diplotricha, an introduced weed, has become a serious problem in coconut orchards. But most common methods used are uprooting and burning. Uprooting is the most efficient method to control this weed and this has to be done at least twice a year.

Good chemical control of Mimosa diplotricha can be achieved by use of glyophosphate, paraquat, diuron, acetochlor plus atrazine, starane etc. A number of pathogenic fungi have been identified as mycoherbicides. Fusarium pallidoroseum, a fungus isolated from Mimosa diplotricha in the Philippines, provided excellent control of mimosa seedlings (Sankaran et.al,2009).

Apart from these mechanical labour weeding has been widely employed in the study areas dealt here in, which is very expensive. Eight labours have to be employed in one acre area in an year with Rupees 600 @ labourer. Bush cutter Machine is another alternative source for weeding which costs Rs 200/hour that means one acre land can be weeded with 4 hours. Nevertheless the operators are reluctant to prefer small areas for weeding but they would prefer large areas to get more income per day. The lack of sufficient labours as well as Bush cutter Machine operators, the farmers have inclined to chemical control which would greatly cause several environmental hazards. The cost incurred for chemical control accounts Rs. 3018/Year which is almost double than Bush cutter Machine weeding. The farmers of Nattika use the Herbicide- Round up (Glyphosphate) $50 \mathrm{ml}$ dissolved in 4 litres of water with $20 \mathrm{gm}$ urea for 3 cents of land. Reasonable evidence suggesting that occupational exposure to phenoxy herbicides results in increased risk of developing non-Hodgkin's lymphoma ( Howard et.al, 1992). Several studies have noted large increases in risk of soft-tissue sarcomas with phenoxy herbicide exposure (Kogevinas, 1997). Some findings have linked herbicide exposure with cancers of the colon, lung, nose, prostate, and ovary as well as to leukemia and multiple myeloma. The results suggest a relationship between exposure to triazine herbicides and increased breast cancer risk (Kettles, 1997). It has been suggested that glyphosate can harm the bacterial ecology of soil and cause micronutrient deficiencies in plants including nitrogen-fixing bacteria (Dick et.al, 2010; Santos et.al, 1995). The four listed above IAS are designated the status of high risk species all over India that is these species cause severe threat to native species and ecological communities (Sankaran et.al,2009). No literature is available pertaining to density status of IAS at any extent till now.

\section{Conclusion:}

Out of the 4 alien invasive species three are of high risk namely Mikania micrantha, Chromolaena odorata and Mimosa diplotricha. Lantana camara is found to be medium risk. The farmers spent a considerable amount of money nearly Rs 4800 per year for one acre land pertaining to mechanical weeding of invasive species. The herbicide is widely used by farmers to control the weeds are capable to cause various health problems including genetic aberration. So an effective and comprehensive weed management strategy have to be developed in the country to combat the threats of IAS in agriculture fields.

\section{Acknowledgments:}

The authors are thankful to Principal, S.N.College, Nattika, Dr. A.R.Raju, and H.O.D. Botany for their valuable support.

\section{References:}

Dick, Richard; Lorenz, Nicola; Wojno, Michal; Lane, Matt (2010). "Microbial dynamics in soils under long-term glyphosate tolerant cropping systems". 19th World Congress of Soil Science. Brisbane, Australia. 113-117.

Howard I. Morrison, Kathryn Wilkins, Robert Semenciw, Yang Mao, Don Wigle (1992).

Kettles, MK; Browning, SR; Prince, TS; Horstman, SW (1997). "Triazine herbicide exposure and breast cancer incidence: An ecologic study of Kentucky counties". Environmental health perspectives. 105 (11): 1222-7.

Kogevinas, M; Becher, H; Benn, T; Bertazzi, PA; Boffetta, P; Bueno-De-Mesquita, HB; Coggon, D; Colin, D et al. (1997). 
"Cancer mortality in workers exposed to phenoxy herbicides, chlorophenols, and dioxins. An expanded and updated international cohort study". American journal of epidemiology. 145 (12): 1061-75.

Sankaran, KV. 2002. Black Wattle Problem Emerges in Indian Forests. CABI Biocontrol News. 23: 1p.

Sankaran, KV; Carol. A. Ellison, T.A.Suresh. 2009. Major invasive alien weeds in India.KFRI Hand book No.24.p 37

Santos, A.; Flores, M. (1995). "Effects of glyphosate on nitrogen fixation of free-living heterotrophic bacteria". Letters in Applied Microbiology. 20 (6): 349-52.

Saxena, 1991. Biological invasions in the Indian subcaontinent: Review of invasion by plants. In:Ramakrishnan, P.S. (ed,). Ecology of biological invasion in the tropics. International Scientific Publication New Delhi. 21-34.

Singh, P. 1998. Lantana weed and lantana lace bug. Indian forester 102: 474-476.

Williamson, M. 1996. Biological invasions, Chapman and Hall.

Article Information

Article history

Received

27 October 2012

Received in revised form

21 November 2012

Accepted

2 December 2012 